\title{
MORUS SPECIES THROUGH CENTURIES IN PHARMACY AND AS FOOD
}

Vojkan M. Miljković1 ${ }^{\star}$, Goran S. Nikolić1 ${ }^{1}$, Ljubiša B. Nikolić ${ }^{1}$, Biljana B. Arsić

${ }^{1}$ Faculty of Technology, University of Niš, Leskovac, Serbia

2 Faculty of Science and Mathematics, University of Niš, Niš, Serbia

The use of various Morus species in pharmacy, as well as in traditional medicine is well known worldwide. In Serbia there is a proverb "Health comes in through the mouth", i.e. through food. So, the aim of the present review paper is the construction of a mosaic from many known uses of Morus species which have been in use through centuries and in different cultures as a remedy, but also as an important nutrient.
(REVIEW PAPER)

UDC 634.38:615

Keywords: mulberry, pharmacy, food

\section{Introduction}

Coloured fruits are good sources of phenolic compounds including anthocyanins, flavonoids and carotenoids [1-4]. Mulberry fruits are rich in phenols and have a unique sour and refreshing taste [5]. They are used as a traditional medicine in curing dental diseases, diabetes, hypertension, arthritis and anemia [6]. With the aim of finding new sources of natural antioxidants, fruits, vegetables and other plants with the antioxidant activity were investigated [7-12].

Genus Morus belongs to Moraceae family, and the names of over 150 species have been published. Different sources usually cite different selections of accepted names. Only 10-16 are generally cited as being accepted by the vast majority of botanical authorities [13]. The best known mulberry species are white mulberry (Morus alba L.), red mulberry (Morus rubra L.) and black mulberry (Morus nigra L.) (Figure 1).

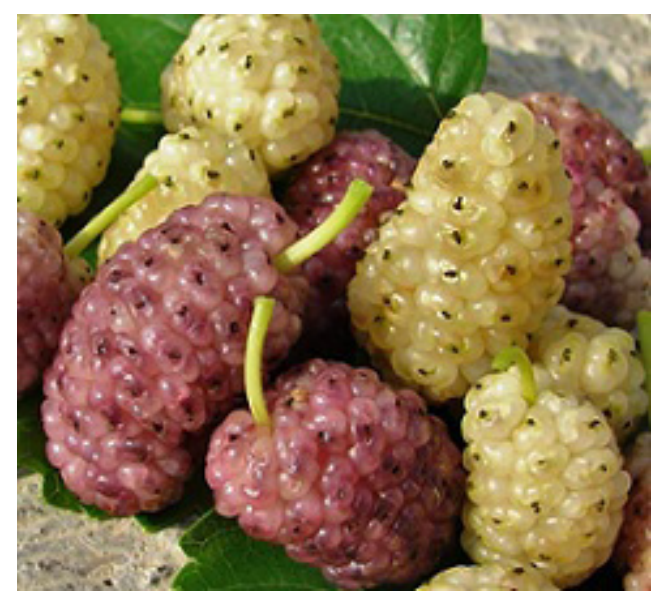

(a)

\footnotetext{
*Author address: Vojkan Miljković, Faculty of Technology,
}

Bulevar oslobođenja 124, 16000 Leskovac, Serbia

E-mail: vojkanmm_serbia@yahoo.com

The manuscript received: December, 02, 2014.

Paper accepted: December, 08, 2014.

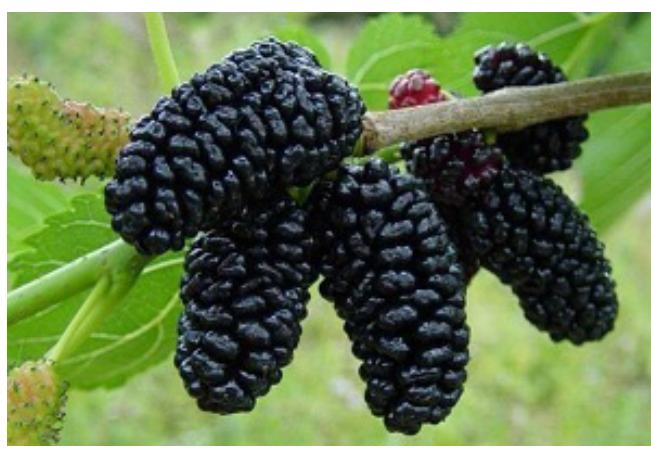

(b)

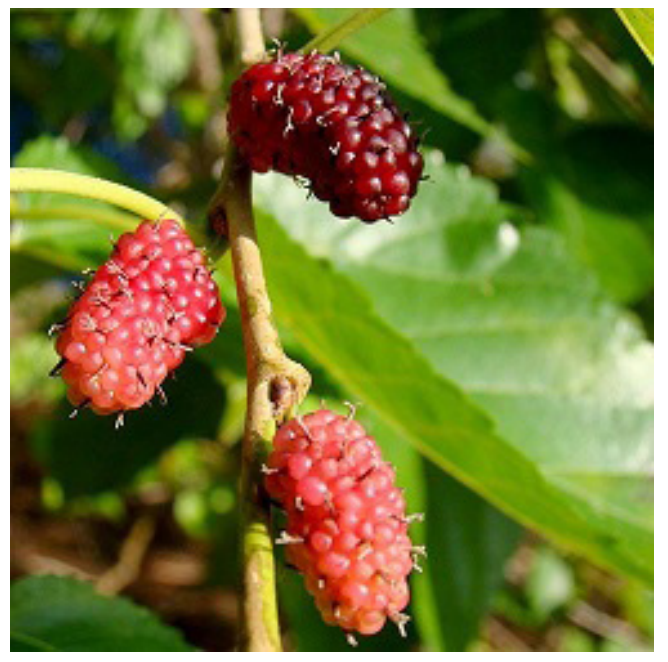

(c)

Figure 1. a) White mulberry (Morus alba L.) b) Red mulberry (Morus rubra L.) c) Black mulberry (Morus nigra L.)

Table 1 gives the scientific mulberry classification. 
Table 1. The scientific mulberry classification

\begin{tabular}{ll}
\hline Kingdom & Plantae \\
Subkingdom & Tracheobionta \\
Division & Magnoliophyta \\
Class & Magnoliopsida \\
Subclass & Hamamelididae \\
Order & Urticales \\
Family & Moraceae \\
Genus & Morus L. \\
Species & Morus alba L., Morus rubra L., Morus nigra L., \\
\hline
\end{tabular}

Morus alba L. is a native to India, China and Japan. It became naturalized in Europe a few centuries ago. The tree was introduced to America for silkworm cultivation in early colonial times and it was naturalized and hybridized with the local red mulberry. White mulberry has a long history of medicinal use in Chinese medicine [14]. Red mulberry or American mulberry originates from the eastern part of the USA and black mulberry came from Asia. Red mulberry fruits arrived in Europe before Roman times. Black mulberry is distributed in Asia, Europe, North and South America and Africa [1, 6].

White mulberry, and to a lesser extent red mulberry, is resistant to drought, pollution and poor land. Black mulberry is more sensitive, particularly in cold climate areas and wet summers. White mulberry is the most resistant among the mentioned three mulberry species, although resistance depends on the clone. Some of them can be harmed at $-3.8^{\circ} \mathrm{C}$, while some of them are durable even to $-31.6^{\circ} \mathrm{C}$. Red mulberry is durable below $0{ }^{\circ} \mathrm{C}$, while black mulberry is very sensitive to low temperatures and the sensitivity varies depending on the clone [3, 4].

All three mulberry trees are deciduous trees of different sizes [15, 16]. White mulberry tree can be 24 meters tall and of different shapes (relaxed or pyramidal). On rich land, red mulberry can be 21 meters tall, while black mulberry is the shortest and can be 9 meters tall. The durability of mulberry depends on the species. Red mulberry very rarely reaches the age of 75 years, while black mulberry can give fruits for centuries.

White mulberry was named after the colour of its buds, not the colour of its fruits [16].

There are excellent review papers on the history and active pharmacokinetic principles of mulberry [17-21]. The aim of this paper is to give a brief summary of its use in pharmacy and as food in different countries and times.

Antimicrobial activity of mulberry

Antimicrobial activities of compounds isolated from different parts of white and black mulberry are presented in Table 2.
Table 2. Antimicrobial activity of compounds isolated from different parts of mulberry

\begin{tabular}{|c|c|c|c|c|c|}
\hline Sample & Compound & $\begin{array}{l}\text { Part of } \\
\text { the plant }\end{array}$ & Activity & $\begin{array}{c}\text { MIC } \\
(\mu \mathrm{g} / \mathrm{ml})\end{array}$ & Literature \\
\hline \multirow{9}{*}{$\begin{array}{c}\text { Morus alba } \\
\text { L. }\end{array}$} & \multirow{9}{*}{ Kuwanon G } & \multirow{9}{*}{ Root } & Streptococcus mutans & 8 & \multirow{9}{*}{ [22] } \\
\hline & & & Streptococcus sanguis & 8 & \\
\hline & & & Streptococcus sobrinus & 8 & \\
\hline & & & Porphyromonas gingivalis & 8 & \\
\hline & & & Staphylococcus aureus & 125 & \\
\hline & & & Actinobacillus & 1000 & \\
\hline & & & Candida albicans & 1000 & \\
\hline & & & Lactobacillus acidophilus & $>1000$ & \\
\hline & & & Lactobacillus casei & $>1000$ & \\
\hline \multirow{6}{*}{$\begin{array}{c}\text { Morus alba } \\
\text { L. }\end{array}$} & \multirow{6}{*}{$\begin{array}{c}\text { Mulberrofuran } \\
\text { G }\end{array}$} & \multirow{6}{*}{ Root } & Candida albicans & $>60$ & \multirow{6}{*}{ [23] } \\
\hline & & & $\begin{array}{c}\text { Saccharomyces } \\
\text { cerevisiae }\end{array}$ & $>60$ & \\
\hline & & & Escherichia coli & 30 & \\
\hline & & & Salmonella typhimurium & 7.5 & \\
\hline & & & $\begin{array}{c}\text { Staphylococcus } \\
\text { epidermis }\end{array}$ & 6.25 & \\
\hline & & & Staphylococcus aureus & 5 & \\
\hline \multirow{7}{*}{$\begin{array}{c}\text { Morus alba } \\
\text { L. }\end{array}$} & \multirow{7}{*}{ Albanol B } & \multirow{7}{*}{ Root } & Candida albicans & $>60$ & \multirow{7}{*}{ [23] } \\
\hline & & & $\begin{array}{c}\text { Saccharomyces } \\
\text { cerevisiae }\end{array}$ & $>60$ & \\
\hline & & & Escherichia coli & 20 & \\
\hline & & & Salmonella typhimurium & 5 & \\
\hline & & & $\begin{array}{c}\text { Staphylococcus } \\
\text { epidermis }\end{array}$ & 5 & \\
\hline & & & Staphylococcus aureus & 5 & \\
\hline & & & Micrococcus luteus & 1.56 & \\
\hline \multirow{6}{*}{$\begin{array}{c}\text { Morus alba } \\
\text { L. }\end{array}$} & \multirow{6}{*}{ Chalcomoracin } & \multirow{6}{*}{ Leaves } & Bacillus subtilis & 3.13 & \multirow{6}{*}{ [23] } \\
\hline & & & Escherichia coli & $>100$ & \\
\hline & & & Klebsiella pneumoniae & $>100$ & \\
\hline & & & $\begin{array}{l}\text { Pseudomonas } \\
\text { aeruginosa }\end{array}$ & $>100$ & \\
\hline & & & Staphylococcus aureus & 125 & \\
\hline & & & Bacillus subtilis & 125 & \\
\hline \multirow{4}{*}{$\begin{array}{l}\text { Morus } \\
\text { nigra L. }\end{array}$} & \multirow{4}{*}{ Extract } & \multirow{4}{*}{ Stem } & Micrococcus flavus & 500 & \multirow{4}{*}{ [24] } \\
\hline & & & Streptococcus faecalis & 500 & \\
\hline & & & Salmonella abony & 250 & \\
\hline & & & $\begin{array}{c}\text { Pseudomonas } \\
\text { aeruginosa }\end{array}$ & 500 & \\
\hline
\end{tabular}

Morus alba L., a good source of ascorbic acid, over $90 \%$ ) is present in the reduced form. It also contains carotene, vitamin B1, folic acid, folinic acid, isoquercetin, quercetin, tannins, flavonoids and saponins [26].

Oxyresveratrol, arylbenzofuran moracin M2, cyclomorusin, morusin, kuwanon $\mathrm{C} 5$, kuwanon $\mathrm{C} 6$, betulinic acid, $\alpha$-amyryn acetate and $\beta$ sitosterol-3-O- $\beta$-Dglucoside were isolated from stems of black mulberry from Botswana [24]. Oxyresveratrol and arylbenzofuran moracin M2 showed antibactericidal activity against Staphylococcus aureus (MBC=125 and $62.5 \mu \mathrm{g} / \mathrm{mL}$, respectively); arylbenzofuran moracin M2 also showed bactericidal activity against Streptococcus faecalis (MBC=500 and $250 \mu \mathrm{g} / \mathrm{ml}$, respectively) [24]. The antibacterial test was conducted on different microorganisms such as Staphylococcus mutants ATCC 25175, known as oral pathogen, Streptococcus sanguis ATCC 35105, Streptococcus sobrinus ATCC 27351, Staphylococcus aureus ATCC 10231, Candida albicans ATCC 10231, Actinobacillus actinomycetemcomitans ATCC 33384, Lactobacillus acidophilus ATCC 4356, Lactoba- 
cillus casei ATCC 4646 and Porphyromonas gingivalis W50.

The antibacterial activity of kuwanon $G$ was investigated by the comparison of MIC with some commercially available appliance in use against caries. MIC of kuwanon $\mathrm{G}$ against Streptococcus was $8 \mu \mathrm{g} / \mathrm{ml}$, which is less comparing to $32 \mu \mathrm{g} / \mathrm{ml}$ of sanguinarine, $125 \mu \mathrm{g} /$ $\mathrm{ml}$ of carvacrol and $500 \mu \mathrm{g} / \mathrm{ml}$ of thymol and eucalyptol which are commercial agents with antibacterial activity. This shows that kuwanon $G$ has a stronger antibacterial activity comparing to commercial agents. Antibacterial activity of kuwanon can be compared with antibiotics such as vancomycin and chlorhexidine which possess harmful effects (change of teeth colour, vomiting, diarrhoea, low immunity) [22].

\section{Mulberry as a medicine}

The main use of mulberry globally is as feed for the silkworm, but depending on the location it is very often appreciated for its fruit which can be consumed fresh, as juice or jam, as a delicious vegetable (young leaves and petioles) and for its medical properties (leaf tea) [26].

Mulberry fruit can be used for various medical purposes because it feeds the skin and blood and as a remedy in case of liver and kidney diseases. Also, it can be used in curing urinary infections, tinnitus, dizziness, constipation in the elderly, anemia, sour throat, fever and depression [27]. The juice obtained from mulberry fruit has delicious taste and smell. Wine can be obtained from mulberry fruit; it is sweet and sour, and is used for purification of blood. Many believe that one glass of this wine per day improves health by cleaning the organism from impurities and enables the ejection of fecal residues in the intestines. Besides, mulberry fruits are rich in anthocyanins, the primary source of antioxidant activities [2834]. Active biomolecules of different mulberry species are kuwanon I, kuwanon I hexamethyl ether, kuwanon I octamethyl ether, 2'-hydroxy-2,4,4'-trimethoxychalcon and 2'-hydroxy-3'-prenyl-2,4,4'-trimethoxychalcone III, mulberrofuran $T$ and kuwanon $E$, morusin, mulberrofuran $D, G, K$, kuwanon $H$, mulberroside $A$, cis-mulberroside $A$, oxyresveratrol, isoquercetin, moracin $E, F, G$ and kuwanon $D, E, F$, deoxynojirimycin-1 etc. from fruits, leaves, roots and barks of white mulberry [35]. These molecules possess healing properties like adstringent, anti-HIV, anti-inflammatory, the purgative effect etc. [3033]. Rubraflavones $A, B, C, D$, which act as laxatives, purgatives, against urinary infections and weakness, were isolated from the root of red mulberry. Deoxynojirimycin, which can be used in the treatment of diabetes, HIV, cancer and high blood pressure, was isolated from the root, leaves and fruit of the black mulberry. Also, it can be used as a purgative [23, 35-39].

Black, white and red mulberry from the area of southeast Serbia have a high content of natural phenolic compounds. Red and black mulberry have a high content of anthocyanins and showed a significant antioxidant activity [40-43].
The researches of the mineral composition showed that mulberry is a rich source of macro and microelements, especially iron [44].

Mulberry in different cultures and through centuries

Today mulberry is mainly in use as animal food. Besides leaves, mulberry possesses sweet fruit of good taste and smell with nutritious elements which are of vital importance for the human metabolism. Mulberry fruit can be used for the preparation of jam, juice, jelly, cellulose, fruit sauces, and cakes. On the Chinese market, mulberry can be consumed in the form of "sangshengao" paste. This paste can be mixed with hot water in order to make tea which improves the functioning of liver and kidneys [45]. Mulberry fruit can be dried and stored as a powder. About $10 \mathrm{~g}$ of dried fruit can give $100 \mathrm{mg}$ of anthocyanins [46]. Because of the presence of resveratrol, mulberry fruit has an antimutagen effect and can inhibit the mutation of healthy and normal cells into cancer cells. It is believed that it can inhibit heart disease, cancer and other diseases connected with chronic inflammation. Fruit as a powder possesses the anti-aging effect. Also, it keeps a normal level of cholesterol and carbohydrates in the human body [38].

In middle ages it was used as a part of the mixture for anesthesia. Hugh of Lucca, the leading surgeon of his period (the $13^{\text {th }}$ century), prepared the sleeping sponge consisting of opium, the juice of the unripe mulberry, hyoscyamus, the juice of hemlock, the juice of the leaves of mandragora, the juice of the wood-ivy, the juice of the forest mulberry, the seeds of lettuce, the seeds of the dock, and the water hemlock [47]. Also, in the middle ages $\left(11^{\text {th }}-14^{\text {th }}\right.$ centuries), pharmacists of the Jewish community of medieval Cairo (according to the lists of materia medica found in Taylor-Schechter Genizah collection, Cambridge) used drugs of the plant origin. Among twenty-eight plants, mulberry was also mentioned [48].

Overripe fruit and sour can be converted into wine with sweet and sour taste. It can be used for the improvement of general vitality of the organism. In Azerbaijan, Georgia and Armenia it is a very popular liqueur "tut araghi" which is consumed to increase potency. It is one of Azerbaijan forms of vodka. It is believed that a small dose of this drink protects the stomach and heart from diseases. In Greece, mulberry fruit is used for the production of traditional, aromatic drink "mouro distillate". In Europe, it is popular for ladies to consume the wine made from mulberry fruit. Because mulberry fruit is rich in anthocyans, it deserves to be exploited for the production of natural colours which are used in the food industry. Specifically, mulberry fruit contains cyanin which is red pigment and gives the red to purple colour to fruits. The main found anthocyanins are cyanidin-3-glucoside and cyanidin-3-rutinoside. These pigments can be used as dietary modulators of the mechanism in case of various diseases and as natural coloured food because there is a need for natural colorants in the food industry [39]. Mulberry fruit can be used as ruminant animal feed [45] 
and in the pharmaceutical industry [49]. The only use of mulberry in modern medicine is for the syrup preparation, added as a natural colour to drugs [46].

\section{Conclusions}

Mulberry is a widespread plant species, very useful in pharmacy and as food. Its health properties have been known from ancient times in old, traditional medicine of India, China, Middle East, etc. The healing properties of mulberry range from depression to the obesity treatment. As fresh food, it gives a pleasant taste and smell, and as processed it serves as a sweet or alcoholic beverage on numerous occasions. In modern medicine, its use is predominantly limited as an additive in syrups and as natural colours.

\section{Acknowledgements}

Vojkan Miljković, Ljubiša Nikolić and Goran Nikolić want to thank the Ministry of Education, Sciences and Technological Development of the Republic of Serbia (project no. 34012) for the financial support.

Biljana Arsić wants to thank the Ministry of Education, Sciences and Technological Development of the Republic of Serbia (project no. 174007) for the financial support.

\section{References}

[1] M. Ozgen, S. Serce, K. Kaya, Phytochemical and antioxidant properties of anthocyanin rich Morus nigra $\mathrm{L}$. and Morus rubra L. fruits, Scientia Horticulturae, 119 (3) (2009) 275-279.

[2] G. Miliauskas, P. R. Venskutonis, T. A. van Beek, Screening of radical scavenging activity of some medicinal and aromatic plant extracts, Food Chemistry, 85(2) (2004) 231-237.

[3] S. Ercisli, E. Orhan, Chemical composition of white (Morus alba L.), red (Morus rubra L.) and black (Morus nigra L.) mulberry fruits, Food Chemistry, 103 (4) (2007) 1380-1384.

[4] D. Gerasopoulos, G. Stavroulakis, Quality characteristics of four mulberry (Morus species) cultivars in the area of Chania, Greece, Journal of the Science of Food and Agriculture, 73 (2) (1997) 261-264.

[5] T. Kutlu, G. Durmaz, B. Ates, I. Yilmaz, M. S. Cetin, Antioxidant properties of different extracts of black mulberry (Morus nigra L.), Turkish Journal of Biology, 35 (1) (2011) 103-110.

[6] A. Sass-Kiss, J. Kiss, P. Milotay, M. M. Kerek, M. TothMarkus, Differences in anthocyanin and carotenoid content of fruits and vegetables, Food Research International, 38 (8-9) (2005) 1023-1029.

[7] F. C. Stinzing, A. S. Stinzing, R. Carle, B. Frei, R. E. Wrolstad, Color and antioxidant properties of cyanidinbased anthocyanin pigments, Journal of Agricultural and Food Chemistry, 50 (21) (2002) 6172-6181.

[8] R. Zadernowski, M. Naczk, J. Nesterowicz, Phenolic acid profiles in some small berries, Journal of Agricultural and Food Chemistry, 53 (6) (2005) 2118-2124.

[9] H. Wang, G. Cao, R. L. Prior, Oxygen radical absorbing capacity of anthocyanin, Journal of Agricultural and Food Chemistry, 45 (2) (1997) 304-309.

[10] H. Ito , Y. Fukuda , K. Murata , A. Kimura, Transformation of intact yeast cells treated with alkali cations, Journal of Bacteriology, 153(1) 163-168.

[11] V. L. Singleton, J. A. Rossi, Colorimetry of total phenolics with phosphomolybdiphosphotungstic acid reagents, American Journal of Enology and Viticulture, 16 (3) (1965) 144-158.

[12] E. Z. Ordom, J. D. Gomez, M. A. Attuone, M. L. Isla, Antioxidant activities of Sechium earle (Jacq.) swart extracts, Food Chemistry, 97 (3) (2006) 452-458.

[13] Economic Division, updated on 27.09.2012. central silk board

[14] A. V. Yadav, V. S. Nade, Anti-dopaminergic effect of the methanolic extract of Morus alba L. leaves, Indian Journal of Pharmacology, 40(5) (2008) 221-226.

[15] T. H. Everett, New illustrated encyclopedia of gardening, Greystone Press, New York, USA, 1960. p. 190.

[16] S. Facciola, Cornucopia: a source book of edible plants, Kampong publ., Vista, California, USA, 1990. p. ix. 676.

[17] S. Bajpai, A. V. B. Rao, M. Muthukumaran, K. Nagalakshmamma, History and active pharmacokinetic principles of mulberry: a review, IOSR Journal of Pharmacy, 2(4) (2012) 13-16.

[18] B. Devi, N. Sharma, D. Kumar, K. Jeet, Morus alba Linn: a phytopharmacological review, International Journal of Pharmacy and Pharmaceutical Sciences, 5 (suppl 2) (2013) 14-18.

[19] R. Singh, A. Bagachi, A. Semwal, S. Kaur, A. Bharadwaj, Traditional uses, phytochemistry and pharmacology of Morus alba Linn.: a review, Journal of Medicinal Plants Research, 7(9) (2013) 461-469.

[20] V. Sharma, S. Chand, P. Singh, Mulberry: a most common and multi-therapeutic plant, International journal of Advanced Research, 1(5) (2013) 375-378.

[21] D. A. Kostic, D. D. Dimitrijevic, S. S. Mitic, M. N. Mitic, G. S. Stojanovic, A. V. Zivanovic, A survey on macro- and micro-elements, phenolic compounds, biological activity and use of Morus spp. (Moraceae), Fruits, 68 (4) (2013) 333-347.

[22] K. M. Park, J. S. You, H. Y. Lee, N. I. Baek, J. K. Hwang, Kuwanon G: an antibacterial agent from the root bark of Morus alba against oral pathogens, Journal of Ethnopharmacology, 84 (2-3) (2003) 181-185.

[23] H. Y. Sohn, K. H. Son, C. S. Kwon, S. S. Kang, Antimicrobial and cytotoxic activity of 18 prenylated flavonoids isolated from medicinal plants: Morus alba L., Morus mongolica Schneider, Broussnetia papyrifera (L.) Vent, Sophora flavescens Ait and Escinosophora koreensis Nakai, Phytomedicine, 11 (7-8) (2004) 666-672.

[24] O. Mazimba, R. R. T. Majinda, D. Motlhanka, Antioxidant and antibacterial constituents of Morus nigra, African Journal of Pharmacy and Pharmacology, 5 (6) (2011) 751754.

[25] N. Khalid, Antimicrobial activity, phytochemical profile and trace minerals of black mulberry (Morus nigra L.) fresh juice, Pakistan Journal of Botany, 43 (Special issue) (2011) 91-96

[26] S. Masilimani, S. M. H. Qadri, S. B. Dandin, Mulberry fruits: a potential value-addition enterprise, Indian Silk, 46 (11) (2008) 12-13

[27] J. Darias-Martin, G. Lobo-Rodrigo, J. HenrnandezCordero, E. Diaz, C. Diaz-Romero, Alcoholic beverages 
obtained from black mulberry, Food Technology and Biotechnology, 41 (2) (2003) 173-176.

[28] Y. Elmaci, T. Altug, Flavour evaluation of three black mulberry (Morus nigra L.) cultivars using GC/MS, chemical and sensory data, Journal of the Science of Food and Agriculture, 82 (6) (2002) 632-635.

[29] T. Katsube, N. Imawaka, Y. Kawano, Y. Yamazaki, K. Shiwaku, Y. Yamane, Antioxidant flavonol glycosides in mulberry (Morus alba L.) leaves isolated based on LDL antioxidant activity, Food Chemistry, 97 (1) (2006) 25-31.

[30] N. Asano, K. Oseki, E. Tomioka, H. Kizu, K. Matsui, $\mathrm{N}$-containing sugars from Morus alba and their glycosidase inhibitory activities, Carbohydrate Research, 259 (2) (1994) 243-255.

[31] P. N. Chen, S. C. Chu, H. L. Chiou, W. H. Kuo, C. L. Chiang, Y. S. Hsieh, Mulberry anthocyanins, cyaniding 3-rutinoside and cyaniding 3-glucoside, exhibited an inhibitory effect on the migration and invasion of a human lung cancer cell line, Cancer Letters, 235 (2) (2006) 248259.

[32] W. Zhang, J. He, Q. Pan, F. Han, C. Duan, Separation and character analysis of anthocyanins from mulberry (Morus alba L.) pomace, Czech Journal of Food Sciences, 29 (3) (2011) 268-276.

[33] J. Du, Z. D. He, R. W. Jiang, W. C. Ye, H. X. Xu, P. P. H. But, Antiviral flavonoids from the root bark of Morus alba L., Phytochemistry, 62 (8) (2003) 1235-1238.

[34] G. Naderi, S. Asgary, N. Sarraf-Zadegan, H. Oroojy, F. Afshin-Nia, Antioxidant activity of three extracts of Morus nigra L., Phytotherapy Research, 18 (5) (2004) 365-369.

[35] K. Rastogi, M. Mehrotra, Compendium of Indian medicinal plants, PID, New Delhi, India, 1990. p. 174-178.

[36] J. A. Duke, Handbook of edible weeds, CRC Press Inc., USA, 1992. p. 246

[37] J. Ahmad, A. H. Farooqui, T. O. Siddiqui, Zakariyaal-Razi's treatise on botanical, animal and mineral origin drugs used for cancer, Acta Pharmacologica et Toxicologica, 59 (Supplement s7) (1986) 277-278.

[38] L. K. Liu, F. P. Chou, Y. C. Chen, C. S. Chyan, H. H. Ho, C. J. Wang, Effects of mulberry (Morus alba L.) extracts on lipid homeostasis in vitro and in vivo, Journal of Agricultural and Food Chemistry, 57 (16) (2009) 7605-7611.

[39] M. M. Giusti, R. E. Wrolstad, UNIT F1.2 Characterization and measurement of anthocyanins by UV-visible spectroscopy, Current Protocols in Food Analytical Chemistry, 2001.
[40] Danijela A. Kostić, Danica S. Dimitrijević, Snežana S. Mitić, Milan N. Mitić, Gordana S. Stojanović and Ana V. Živanović, Phenolic Content and Antioxidant Activities of Fruit Extracts of Morus nigra L. (Moraceae) from Southeast Serbia, Tropical Journal of Pharmaceutical Research, 12 (1) (2013) 105-110.

[41] D. A. Kostić, D. S. Dimitrijević, G. S. Stojanović, S. S. Mitić, M. N. Mitić Phenolic Composition and Antioxidant Activity of Fresh Fruit Extracts of Mulberries From Serbia, Oxidation Communications 36 (1) (2013) 4-14.

[42] Danica S. Dimitrijević, Danijela A. Kostić, Gordana S.Stojanović, Snežana S. Mitić, Milan N. Mitić, Ružica Micić, Polyphenol contents and antioxidant activity of five fresh fruit Morus spp. (Moraceae) extracts, Agro food High teach, 3 (2013) 10-14.

[43] Danica S. Dimitrijević, Danijela A. Kostić, Gordana S. Stojanović, Snežana S. Mitić, Milan N. Mitić, Aleksandra S. Đorđević, Phenolic composition, antioxidant activity, mineral content and antimicrobial activity of fresh fruit extracts of morus alba I. , Journal of Food and Nutrition Research , 1 (53) (2014) 22-30.

[44] Danijela A. Kostić, Danica S. Dimitrijević, Gordana S. Stojanović, Snezana S. Mitić, Milan N. Mitić, Saša S. Ranđelović, Aleksandra Pavlović, Ruzica Micić Content of heavy metals in mulberry fruits and their extracts, correlation analysis, AJAC 4 (2013) 674-682.

[45] T. W. Kim, Y. B. Kwon, J. H. Lee, I. S. Yang, A study on the antidiabetic effect of mulberry fruits, Korean Journal of Sericultural Science, 38 (2) (1996) 100-107.

[46] B. K. Singhal, A. Dhar, M. A. Khan, B. B. Bindroo, R. K. Fotedar, Potential economic additions by mulberry fruits in sericulture industry, Plant Horti Tech, 9(1) (2009) 47-51.

[47] V. Robinson, Victory over pain, a history of anesthesia, Henry Schuman: New York, 1946.

[48] E. Lev, Drugs held and sold by pharmacists of the Jewish community of medieval (11th-14th centuries) Cairo according to lists of materia medica found at the TaylorSchechter Genizah collection, Cambridge, Journal of Ethnopharmacology, 110(2) (2007) 275-293.

[49] G. Habib, Mulberry fruit based feed blocks-a key supplement for livestock in mountainous regions, Mountain Research and Development, 24 (2) (2004) 106109.

Izvod

\section{MORUS VRSTA KROZ VEKOVE U FARMACIJI I KAO HRANA}

Vojkan M. Miljković ${ }^{1}$, Goran S. Nikolić ${ }^{1}$, Ljubiša B. Nikolić1 ${ }^{1}$ Biljana B. Arsić ${ }^{2}$

\footnotetext{
1 Tehnološki fakultet, Univerzitet u Nišu, Leskovac, Srbija

2 Prirodno-matematički fakultet, Univerzitet u Nišu, Niš, Srbija
}

Upotreba različitih vrsta Morus u farmaciji kao i u tradicionalnoj medicini je dobro poznata širom sveta. U Srbiji postoji izreka koja kaže: „Zdravlje na usta ulazi“. Zato je cilj ovog rada bio da da pregled upotreba vrsta Morus koje se primenjuju kroz vekove u različitim kulturama, kao lek, ali i kao važan deo ishrane.
(PREGLEDNI RAD)

UDC 634.38:615

Ključne reči: dud, farmacija, hrana 